\title{
Association between a polymorphism in intron 3 of the bovine growth hormone gene and growth traits in Holstein heifers in Antioquia
}

\author{
J. Arango, J.J. Echeverri and A. López \\ Biodiversity and Molecular Genetics Research Group - BIOGEM Department \\ of Animal Production, School of Agricultural and Livestock Sciences, \\ Universidad Nacional de Colombia, Antioquia, Medellin, Colombia \\ Corresponding author: J.J. Echeverri \\ E-mail: jjecheve@unal.edu.co / jjez69@hotmail.com
}

Genet. Mol. Res. 13 (3): 6191-6199 (2014)

Received June 28, 2013

Accepted February 10, 2014

Published August 15, 2014

DOI http://dx.doi.org/10.4238/2014.August.15.1

\begin{abstract}
The aim of this study was to determine the association between a polymorphism in intron 3 of the bovine growth hormone (BGH) gene and growth traits related to the start of the reproductive life of Holstein heifers. This research was conducted using 480 Holstein heifers belonging to eight herds in three municipalities in the Department of Antioquia (Colombia). The phenotypic information used corresponded to information that had been historically recorded for each of the herds and was supplemented with information obtained through bimonthly visits to the herds over a period of 24 months. Genotyping was performed using the PCR-RFLP technique with DNA extracted from peripheral blood using the salting out technique. To determine association, statistical analyses were performed using parametric methods. Allele frequencies for the alleles $(+)$ and $(-)$ were 0.91 and 0.09 , respectively. The genotype frequencies were $0.77,0.2$ and 0.03 for the genotypes $(+/+),(+/-)$ and $(-/-)$, respectively. There was an association between genotype and weight at first estrus and first calving $(\mathrm{P}<0.01)$. The regression coefficients for both characteristics were
\end{abstract}


significant, indicating that for each $(+)$ allele, weight at first estrus and first calving decreased by 9.24 and $16.07 \mathrm{~kg}$, respectively. The results indicated the existence of an association between a polymorphism in intron 3 of the BGH gene and both weight at first estrus and first calving, which can be used to facilitate the selection of animals with these genotypes for use in breeding programs.

Key words: PCR-RFLP; Molecular markers; Animal production; Growth traits

\section{INTRODUCTION}

In specialized dairy farms, achieving a high biological and economic efficiency requires high milk production and good reproductive performance (Marini et al., 2007). Two of the factors that influence productivity are the age and weight of the heifers when they reach reproductive maturity because of the reduction in the nursery period and rapid growth, which allows the heifers to reach reproductive stage earlier, resulting in a longer and more productive life (Villalobos and Armando, 2005).

The weight of the heifer, more than the age, determines the onset of puberty and first estrus (Villalobos and Armando, 2005, González et al., 2007). The first sign of this usually appears when the heifer has reached $60 \%$ of its adult weight; however, some heifers achieve this state at a lower weight, in which case estrus should be avoided. Therefore, weight and body development are more valid criteria than age for deciding when first estrus will be reached in a heifer (Villalobos and Armando, 2005).

Another challenge to the farmer, besides that of guaranteeing that the animal reaches puberty, is to manage calving so that it happens when the cow reaches $80-85 \%$ of its adult weight; poor nutrition, low weight and poor development during this period result in delays in the return of postpartum ovarian activity, estrus without ovulation, silent estrus, and embryonic mortality (Villalobos and Armando, 2005).

The complex system of the somatotropic axis plays a key role in controlling the development of animals. The genes that operate in this system are responsible for postnatal growth, especially the bovine growth hormone $(\mathrm{BGH})$ gene, which affects different aspects of growth, including the development of bones, muscles and tissues (Sellier, 2000; Pereira et al., 2005; Echeverri et al., 2011). BGH is a synthesized anabolic agent that is secreted in a circadian and pulsating manner by the somatotropic cells of the anterior lobe of the hypophysis (Ayuk and Sheppard, 2006), which are primarily responsible for linear growth, development, lactation, and reproduction (McMahon, 2001; Akers, 2006; Ayuk and Sheppard, 2006; ThidarMyint et al., 2008). It has been reported that some allelic variations of the BGH gene are associated with characteristics of carcass growth and weight (Grochowska et al., 2001) and weight at birth (Biswas et al., 2003) in dairy cattle.

In industry, the growth parameters of the animals are of great concern during breeding due to their decisive economic value (Hua et al., 2009). The association of this gene polymorphism with growth characteristics makes it a candidate for use in programs that use marker-assisted selection to predict growth characteristics. It could also be used as a tool for selecting animals that are entering early reproductive stages and to help prevent economic 
losses that are caused by inefficient breeding of the animals prior to maturity (Aruna et al., 2004). The aim of this study was to determine the association of a polymorphism in intron 3 of the BGH gene with growth characteristics related to the beginning of reproductive life in Holstein heifers in the Department of Antioquia (Colombia).

\section{MATERIAL AND METHODS}

We used 480 heifers of the Holstein breed belonging to eight dairy herds located in the highland tropics of Antioquia in the municipality of San Pedro de los Milagros [altitude: 2475 $\mathrm{m}$ above sea level (masl), temperature (T): $14^{\circ} \mathrm{C}$ ], Belmira (altitude: 2550 masl, T: $14^{\circ} \mathrm{C}$ ) and the Santa Elena township of Medellin (altitude: 2500 masl, T: $17^{\circ} \mathrm{C}$ ). The phenotypic information that was used corresponded to information that had been previously recorded for each of the herds with supplemented information obtained through bimonthly visits to the herds over a period of 24 months.

\section{DNA extraction and determination of genotype variants}

To determine allelic and genotypic variables, blood was collected from coccygeal vein and DNA extraction was performed following the salting out technique described by Miller et al. (1988).

Genomic DNA purity was determined by absorbance analysis at two wavelengths. Only genomic DNA of ideal purity with an absorbance ratio of 1.8-2.0 was used for further molecular analysis.

The primers used to amplify the specific region of intron 3 of the BGH gene that contains the polymorphism were described by Dybus (2002) and are as follows: F (5'CCCACGGGCAAGAATGAGGC-3') and R (5'-TGAGGAACTGCAGGGGCCCA-3'). The amplification was performed using a final volume of $25 \mu \mathrm{L}$ containing $2.5 \mu \mathrm{L}$ 10X PCR buffer (1.0-1.5 mM MgCl$, 50 \mathrm{mM} \mathrm{KCl}, 10 \mathrm{mM}$ Tris-HCl, $\mathrm{pH} 8.3), 0.2 \mu \mathrm{M}$ of each primer, $0.4 \mathrm{mM}$ of each dNTP, $2 \mathrm{mM} \mathrm{MgCl}$, 1 U Taq DNA polymerase, and 30-60 ng genomic DNA.

PCR was performed in a thermocycler. The amplification conditions for intron 3 of the $\mathrm{BGH}$ gene were an initial denaturation at $94^{\circ} \mathrm{C}$ for $5 \mathrm{~min}$, denaturation at $94^{\circ} \mathrm{C}$ for $1 \mathrm{~min}$, primer alignment (annealing) at $55^{\circ} \mathrm{C}$ for $1 \mathrm{~min}$, and extension at $72^{\circ} \mathrm{C}$ for $1 \mathrm{~min}$. Steps two to four were repeated for 39 cycles, and the reaction ended with an extension step of $3 \mathrm{~min}$ at $72^{\circ} \mathrm{C}$ to terminate the reaction (Dybus, 2002).

The annealing temperature used was determined following the recommendation of the primer distributors and by various tests that yielded a more efficient alignment at the aforementioned temperature $\left(55^{\circ} \mathrm{C}\right)$ (Dybus, 2002). As a positive control for all reactions, amplifications were performed in samples that were previously evaluated and negative control reactions were performed in the absence of DNA.

Genotypic variants were determined using RFLP (restriction fragment length polymorphism) with the restriction enzyme $M s p \mathrm{I}$. A final volume of $20 \mu \mathrm{L}$ was used for digestion that contained $5 \mu \mathrm{L}$ PCR product, $2 \mu \mathrm{L} 1 \mathrm{X}$ Tango buffer and $12.5 \mu \mathrm{L}$ ultrapure water. The reaction products were digested with $5 \mathrm{U}$ of the restriction enzyme $M s p \mathrm{I}$ for $3 \mathrm{~h}$ at $37^{\circ} \mathrm{C}$. The product was observed on a $2.5 \%$ agarose gel and stained with ethidium bromide.

The expected restriction pattern for genotype (-/-) was a fragment of $329 \mathrm{bp}$, for genotype $(-/+)$ three fragments (329, 224 and $105 \mathrm{bp})$, and for genotype (+/+) two fragments (224 and $105 \mathrm{bp})$. 


\section{Estimation of allele frequencies}

The frequencies of the different alleles were estimated by measuring the proportion of each form of the gene compared to the total number of copies in the study population. We identified both homozygotes (two copies of the same allele) and heterozygous (one copy of each allele) and calculated the frequency (F) of each allele by counting the homozygotes and adding half the heterozygotes following the method described by Hartl (2000).

Total frequency (p) of allele 1 in the population:

$\mathrm{p}=\mathrm{Fa} / \mathrm{a}+1 / 2 \mathrm{Fa} / \mathrm{b}$

Total frequency $(\mathrm{q})$ of allele 2 in the population:

$\mathrm{q}=\mathrm{Fb} / \mathrm{b}+1 / 2 \mathrm{Fa} / \mathrm{b}$, where;

$\mathrm{Fa} / \mathrm{a}$ and $\mathrm{Fb} / \mathrm{b}=$ homozygous

$\mathrm{Fa} / \mathrm{b}=$ heterozygous

\section{Statistical analysis}

To determine the association of each of the features with the genotype of intron 3 of the BGH gene, generalized linear models were adjusted on the basis of known sources of variation for each of the dependent variables (weight at first estrus, weight at first calving and daily weight gain). The Tukey test was used to determine differences between the means for each of the levels of the fixed effects that were included in the model. We used the SAS 9.2 statistical software for all of the analyses (SAS Inst. Inc., 2009).

The following general model of fixed effects was employed:

$\mathrm{Y}_{\mathrm{ijk} \mid m n o p}=\mu+\mathrm{G}_{\mathrm{i}}+\mathrm{H}_{\mathrm{j}}+\mathrm{AN}_{\mathrm{k}}+\mathrm{MN}_{1}+\left(\mathrm{MN}^{*} \mathrm{AN}\right)_{\mathrm{m}}+\left(\mathrm{H}^{*} \mathrm{AN}\right)_{\mathrm{n}}+\left(\mathrm{H}^{*} \mathrm{MN}\right)_{\mathrm{O}}+\left(\mathrm{H}^{*} \mathrm{MN} * \mathrm{AN}\right)_{\mathrm{P}}+\mathrm{e}_{\mathrm{ijk} k m n o p}$

where:

$\mathrm{Y}_{\mathrm{ijklmnop}}$ : weight at first estrus, weight at first calving or daily weight gain of individual $\mathrm{X}$, carrier of genotype $i$, located in herd $j$, with year of birth $k$ and birth month $l$.

$\mu$ : mean for the feature.

$\mathrm{G}_{\mathrm{i}}$ : fixed effect of the genotype for BGH $(\mathrm{i}=1 \ldots 3)$.

$\mathrm{H}_{\mathrm{i}}$ : fixed effect of the herd $(\mathrm{j}=1 \ldots 8)$.

$\mathrm{AN}_{\mathrm{k}}$ : fixed effect of the year of birth $(\mathrm{k}=1 \ldots 15)$.

$\mathrm{MN}_{1}$ : fixed effect of the month of birth $(1=1 \ldots 12)$.

$\left(\mathrm{MN}^{*} \mathrm{AN}\right)_{\mathrm{m}}$ : fixed effect of the interaction between the month of birth and the year of birth $(\mathrm{m}=1 \ldots 86)$. $1 \ldots 46)$.

$\left(\mathrm{H}^{*} \mathrm{AN}\right)_{\mathrm{n}}$ : fixed effect of the interaction between the herd and the year of birth $(\mathrm{n}=$

$\left(\mathrm{H}^{*} \mathrm{MN}\right)_{\mathrm{o}}$ : fixed effect of the interaction between the herd and the month of birth (o $=1 \ldots 68)$.

$\left(\mathrm{H}^{*} \mathrm{MN} * \mathrm{AN}\right)_{\mathrm{p}}$ : fixed effect of the interaction between the herd, month of birth and year of birth $(p=1 \ldots 41)$.

$\mathrm{e}_{\mathrm{ijk} k \mathrm{lmop}}$ : experimental error. 
The effect of all interactions alone was used to model daily weight gain. For models of weight at first estrus and weight at first calving, the effects of the covariables at age of first estrus and age at first birth were included, respectively.

A simple linear regression analysis was performed using the SAS 9.2 software to determine the relationship of the allelic effect and the study variables. To this end, the genotypes $0(-/-), 1(+/-)$ and $2(+/+)$ were re-scaled to a quantitative scale using the following model:

$$
\mathrm{Y}_{\mathrm{i}}=\beta_{0}+\beta_{1} \mathrm{X}_{\mathrm{i}}+\mathrm{e}_{\mathrm{i}}
$$

where:

$\mathrm{Y}_{\mathrm{i}}$ : value for the dependent variable (weight at first estrus, weight at first calving and daily weight gain for the individual) as a function of the number of $(+)$ alleles.

$\beta_{0}$ : intercept

$\beta_{1}$ : linear regression coefficient estimated for the allele substitution $(+)$

$X_{i}$ : number of $(+)$ alleles in the individual (i.e., $\left.0,1,2\right)$.

$\mathrm{e}_{\mathrm{i}}$ : residual error.

\section{RESULTS}

A 329-bp DNA fragment was amplified for 408 animals. Analysis of the restriction fragments using the enzyme $M s p$ I generated the following two restriction patterns: a 329-bp fragment corresponding to the (-) allele, and two fragments of 224 and $105 \mathrm{bp}$ corresponding to the $(+)$ allele. The allele frequencies of the $(+)$ and $(-)$ alleles were 0.91 and 0.09 , respectively. The genotype frequencies were $0.77,0.2$ and 0.03 for the genotypes $(+/+),(+/-)$ and $(-/-)$, respectively.

\section{Descriptive analysis of the growth features of Holstein heifers}

The average weight for the Holstein heifers was $379.2 \pm 55.7 \mathrm{~kg}$ at first estrus and $519.7 \pm 66.8 \mathrm{~kg}$ at first calving, and the average daily weight gain was $0.51 \pm 0.16 \mathrm{~kg} / \mathrm{day}$.

The characteristic with the highest variability was daily weight gain, with a coefficient of variation of $30.9 \%$. The weight at first estrus and calving had low variability in the population of Holstein heifers. The average values for all of the features were within the normal reported ranges. Table 1 summarizes the descriptive statistics for all of the features.

Table 1. Mean, standard deviation (SD) and coefficient of variation (CV) for weight at first estrus, weight at first calving and daily weight gain of the Holstein heifers of Antioquia.

\begin{tabular}{lcccc}
\hline Feature & N & Mean & SD & CV \\
\hline Weight at first estrus (kg) & 476 & 379.2 & 55.7 & $14.6 \%$ \\
Weight at first calving (kg) & 419 & 519.7 & 66.8 & $12.8 \%$ \\
Daily weight gain (kg/day) & 412 & 0.51 & 0.16 & $30.9 \%$ \\
\hline
\end{tabular}

\section{Genotype effect on growth features}

Genotype had a significant effect $(\mathrm{P}<0.05)$ on weight at first estrus; the model showed 
a coefficient of determination of 0.97, i.e., genotype, herd, year of birth, age at first estrus, and month of birth explained $97 \%$ of the variance in weight at first estrus. Tukey analysis revealed a highly significant difference between the means $(\mathrm{P}<0.01)$ of the genotypes, indicating that animals with genotype (-/-) weighed $28.15 \mathrm{~kg}$ more than the animals with genotype $(+/+)$. Individuals with genotype $(+/-)$ weighed $6.77 \mathrm{~kg}$ more at first estrus than the animals with genotype $(+/+)$ (Table 2$)$.

Table 2. Association between the polymorphism in intron 3 of the bovine growth hormone (BGH) gene and weight at first estrus, weight at first calving and daily weight gain of the Holstein heifers of Antioquia.

\begin{tabular}{lccc}
\hline Genotype & Weight at first estrus $(\mathrm{kg})$ & Weight at first calving $(\mathrm{kg})$ & Daily weight gain $(\mathrm{kg} /$ day $)$ \\
\hline$(+/+)$ & $373.61^{\mathrm{a}}$ & $514.0^{\mathrm{a}}$ & $0.52^{\mathrm{a}}$ \\
$(+/-)$ & $380.38^{\mathrm{b}}$ & $518.8^{\mathrm{a}}$ & $0.52^{\mathrm{a}}$ \\
$(-/)$ & $401.76^{\mathrm{c}}$ & $587.6^{\mathrm{b}}$ & $0.55^{\mathrm{a}}$ \\
\hline
\end{tabular}

Different letters in the same column indicate significant differences $(\mathrm{P}<0.05)$.

Genotype had a highly significant effect $(\mathrm{P}<0.01)$ on weight at first calving; the model had a coefficient of determination of 0.97 , indicating that the effects of the genotype, herd, year of birth, month of birth, and age at first birth explained $97 \%$ of the variance observed for this feature. Tukey analysis revealed significant differences between the animals with different genotypes $(\mathrm{P}<0.05)$; animals with genotype $(-/-)$ weighed 73.6 and $68.7 \mathrm{~kg}$ more than animals with the genotypes (+/+) and (+/-), respectively (Table 2$)$.

For daily weight gain, the genotype did not have a significant effect $(\mathrm{P}>0.05)$. However, genotype (-/-) was superior to the rest of the individuals. The model showed a coefficient of determination of 0.82 , indicating that the effects of herd, year of birth, month of birth and the interactions between the month and year of birth, between the herd and year of birth and between the herd and the month and year of birth can explain $82 \%$ of the variation in daily weight gain. Tukey analysis showed no significant differences between the genotypes $(\mathrm{P}>0.05)$ (Table 2).

\section{Allele substitution effect of the polymorphism in intron 3 of the BGH gene on the growth features of Holstein heifers in Antioquia}

The regression coefficient $(\beta)$ for weight at first estrus was -9.24 , indicating that for each $(+)$ allele provided by the individual, the weight at first estrus decreased by $9.24 \mathrm{~kg}$. For weight at first calving, a $\beta$ of -16.0 was obtained, which means that for each $(+)$ allele, first calving weight decreased by $16.0 \mathrm{~kg}$. The estimated regression coefficient for the average daily gain was not statistically significant $(\mathrm{P}>0.05)$. The $\beta$ for this feature was -0.008 , indicating that for each $(+)$ allele the average daily weight gain decreased by $0.008 \mathrm{~kg}(8 \mathrm{~g})$. The regression coefficients for each of the features are shown in Table 3.

Table 3. Regression coefficients for weight at first estrus, weight at first calving and daily weight gain of the Holstein heifers of Antioquia.

\begin{tabular}{lccc}
\hline Feature & Intercept $(\mathrm{I})$ & Beta $(\beta)$ & Standard error $\beta$ \\
\hline Weight at first estrus $(\mathrm{kg})$ & 391.81 & -9.24 & 1.94 \\
Weight at first calving $(\mathrm{kg})$ & 545.37 & -16.0 & 4.57 \\
Daily weight gain $(\mathrm{kg})$ & 0.53 & -0.008 & 0.031 \\
\hline
\end{tabular}


The estimated regression coefficient for the characteristics of weight at first estrus and first calving was highly significant $(\mathrm{P}<0.01)$ and for daily weigh gain was significant $(\mathrm{P}$ $<0.05)$.

\section{DISCUSSION}

The genotype and allele frequencies obtained in this study are similar to those reported by Gorbani et al. (2009) in a population of 183 Holstein animals, where the frequencies were $0.787,0.191$ and 0.022 for the genotypes $(+/+),(+/-)$ and $(-/-)$, respectively, and were 0.883 and 0.117 for the alleles $(+)$ and $(-)$, respectively.

Pereira et al. (2005) found an association of a polymorphism in the BGH gene in the fifth exon at position +2141 (a substitution of a cytosine $(C)$ to a guanine $(G)$ that causes a change from the amino acid leucine (L) to valine $(\mathrm{V})$ in the protein) by weight at first year in a Charolais $\mathrm{x}$ Zebu cross population. The authors mention the superiority of the genotype LL with respect to LV for this feature, highlighting that the $\mathrm{V}$ allele increases the weight at first year. The features of weight at birth and the weight at weaning showed no associations.

Reis et al. (2001) found that the LV genotype was positively associated with greater weight during the later stages of growth in meat-producing Portuguese breeds (from $70 \%$ of the live weight to slaughter); however, for both studies, the small sample sizes did not allow the effect of the VV genotype to be determined. Other studies by Chrenek et al. (1998) reported that the VV genotype was associated with lower body weight and daily weight gain in Simmental bulls compared with the LL and LV genotypes.

Studies on the associations of intron 3 polymorphisms in the BGH gene with growth features are scarce. However, there are some reports that have focused primarily on beef cattle, which makes this study a pioneer in correlating dairy cattle growth features with the polymorphism in question.

Unanian et al. (2000) documented an influence of the DD genotype (corresponding to genotype (-/-) of the $\mathrm{BGH} / \mathrm{Msp}$ I on the average daily weight gain 14 months after weaning. The influences of genotype on birth weight, weaning weight and daily weight gain from weaning to 12,13 and 14 months were studied, and no significant differences between genotypes were found. Allele frequencies of the Nellore cattle breed that was used in that study demonstrate that the dominant allele $\mathrm{D}$ appears more often in Zebu dairy cattle, while the $\mathrm{C}$ allele is more prevalent in Bos taurus dairy cattle (Lagziel et al., 2000; Unanian et al., 2000; Gorbani et al., 2009). The study also demonstrates that the $\mathrm{D}$ allele, which is favorable and highly frequent in Zebu dairy cattle and correlates with the average daily weight gain from weaning to 14 months, has a low frequency in the genus $B$. taurus. Therefore, differences between these two species were found.

The studies of Lagziel et al. (2000), Unanian et al. (2000) and Gorbani et al. (2009) agree with the results of this study where the (-) allele, which is the same as the D allele mentioned above, had a low frequency in Holstein cattle, which could explain why Bos indicus cattle are used for meat production; they have a strong influence and dominance of this genotype, which is favorable for growth and weight gain.

Some reports in other studies have suggested that the $(+/+)$ (or the genotype $\mathrm{C}$ in the study mentioned above) genotype of intron 3 of the BGH gene is the most favorable for milk and protein production (Dybus, 2002; Zwierzchowski et al., 2002). These Holstein popula- 
tions have been used for directed matings (artificial selection) to achieve a higher volume of milk production and could explain why the genotype (-/-), which was favorable for weight gain, had a low frequency in livestock that is specialized for milk production, which is different from Zebu cattle.

Although there are clear trends in the associations between the genotype of the BGH gene and weight at first breeding and first calving, the low frequency of some of the registered genotypes makes it difficult to determine the degree of association with each of the evaluated features. Therefore, an increased sample size is required to obtain more confident results.

These results are the first to report a link between weight at first estrus, weight at first calving and daily gain weight with a polymorphism in intron 3 of the BGH gene in Holstein cattle of the high Colombian tropics. Associations with these features can be used to select individuals with favorable genotypes for breeding programs.

\section{REFERENCES}

Akers RM (2006). Major advances associated with hormone and growth factor regulation of mammary growth and lactation in dairy cows. J. Dairy Sci. 89: 1222-1234.

Aruna P, Chakravarty A, Bhattacharya T, Joshi B, et al. (2004). Detection of polymorphism of growth hormone gene for the analysis of relationship between allele type and growth traits in Karan Fries cattle. J. Anim. Sci. 17: 1334-1337.

Ayuk J and Sheppard MC (2006). Growth hormone and its disorders. Postgrad. Med. J. 82: 24-30.

Biswas TK, Bhattacharya TK, Narayan AD, Badola S, et al. (2003). Growth hormone gene polymorphism and its effect on birth weight in cattle and buffalo. J. Anim. Sci. 16: 494-497.

Chrenek P, Kmef J, Sakowski I, Vasiicek D, et al. (1998). Relationships of growth hormone genotypes with meat production traits of Slovak Pied bulls. Czech. J. Anim. Sci. 43: 541-544.

Dybus A (2002). Associations of growth (GH) and prolactin (PRL) genes polymorphisms with milk production traits in Polish Black and White cattle. Anim. Sci. P. 20: 203-212.

Echeverri J, López A, Arango J, Rodríguez N, et al. (2011). Marcadores Moleculares en Producción Bovina. Primera edición. Universidad Nacional de Colombia, Medellín.

González C, Madrid N, Gocichea J, Villalobos D, et al. (2007). Primer servicio en novillas de doble propósito. Rev. Cient. 13: 39-46.

Gorbani A, Vaez T, Bonyadi M and Amirinia C (2009). A MspI PCR-RFLP within bovin growth hormone gene and its association with sperm quality traits in Iranian Holstein bulls. Afr. J. Biotechnol. 8: 4811-4816.

Grochowska R, Lunden A, Zwierchowski L, Snochowski M, et al. (2001). Association between gene polymorphism of growth hormone and carcass traits in dairy bulls. Anim. Sci. 72: 441-447.

Hartl D (2000). A Primer of Populations Genetics. 3rd edn. Sinauer Associates, Inc., Publishers, Sunderland, 26-31.

Hua GH, Chen SL, Yu JN, Cai KL, et al. (2009). Polymorphism of the growth hormone gene and its association with growth traits in Boer goat bucks. Meat Sci. 81: 391-395.

Lagziel A, DeNise S, Hanotte O, Dhara S, et al. (2000). Geographic and breed distribution of an Msp I PCR-RFLP in the bovine growth hormone (bGH) gene. Anim. Genet. 31: 210-213.

Marini P, Charmandarian D and Masso R (2007). Desempeño Productivo y Reproductivo de Vacas de Diferentes Edades al Primer Parto en Sistemas a Pastoreo. Argentine Animal Production Site, Cusco.

McMahon CD, Radcliff RP, Lookingland KJ and Tucker HA (2001). Neuroregulation of growth hormone secretion in domestic animals. Domest. Anim. Endocrinol. 20: 65-87.

Miller SA, Dykes DD and Polesky HF (1988). A simple salting out procedure for extracting DNA from human nucleated cells. Nucleic Acids Res. 16: 1215.

Pereira A, Maurício M, Henrique $\mathrm{N}$ and Luciana C (2005). Association of $G H$ and $I G F 1$ polymorphisms with growth traits in a synthetic beef cattle breed. Genet. Mol. Biol. 28: 230-236.

Reis C, Navas D, Pereira M and Cravador A (2001). Growth hormone Alui polymorphism analysis in eight Portuguese bovine breeds. Arch. Zootec. 50: 41-48.

SAS 9.2 (2009). SQL Procedure User's Guide. SAS Institute, Cary.

Sellier P (2000). Genetically caused retarded growth in animals. Domest. Anim. Endocrinol. 19: 105-119.

ThidarMyint H, Yoshida H, Ito T, He M, et al. (2008). Combined administration of ghrelin and GHRH synergistically 
stimulates GH release in Holstein preweaning calves. Domest. Anim. Endocrinol. 34: 118-123.

Unanian M, Barreto C, Freitas A, Cordeiro C, et al. (2000). Associação do polimorfismo do gene do hormônio de crescimento com a caraterística peso em bovinos da raça Nelore. Rev. Bras. Zootec. 29: 1380-1386.

Villalobos D and Armando M (2005). Manejo de Las Novillas de Reemplazo. Manual de Ganadería Doble Propósito. Unidad de Investigación en Producción Animal, Facultad de Ciencias Veterinarias, Universidad del Zulia, Maracaibo.

Zwierzchowski L, Krzyzeweski J, Strzalkowska N, Siadkowska E, et al. (2002). Effects of polymorphism of growth hormone (GH), Pit-1, and Leptin (LEP) genes, cow's age, lactation stage and somatic cell count on milk yield and composition of Polish black-and-white cows. Anim. Sci. Papers Rep. 20: 213-227. 